\title{
Modeling of Logging Industry Dynamics Under the Global Climate Change: the Evidence from Siberian Regions
}

\author{
Anna V. Chugunkova* \\ Siberian Federal University \\ Krasnoyarsk, Russian Federation
}

Received 14.06.2020, received in revised form 19.10.2020, accepted 13.11.2020

\begin{abstract}
As a part of global economy, forestry experiences influence of diverse factors and global climate change in particular, which can affect forestry directly or indirectly via changes in qualitative and quantitative assessment of forest growing stocks, and in positive or negative manner. Climate change effects on Russian forestry are still poorly studied and call for more attention in policy-making. One of the direct impacts is shortening of winter logging season duration, which may result in decreasing wood harvests. Using the data on logging volumes in Krasnoyarsk Krai and Irkutsk Oblast and estimated duration of winter logging season on meteorological stations for the retrospective period of 19662018, eight ARDL models were evaluated. The modeling results supported the idea of dependence of harvested wood volumes on winter logging season duration across all considered meteorological stations. To reduce negative impacts on logging industry in terms of wood harvest reduction, adaptation activities in forestry are sorely needed.
\end{abstract}

Keywords: global climate change, forestry, logging season, logging volumes, autoregressive distributed lag model.

The study was funded by the Russian Science Foundation (project 19-18-00145). Author thanks Dr. Anton I. Pyzhev for helpful comments and suggestions on time-series modeling.

Research area: economics and national economy management.

\footnotetext{
(C) Siberian Federal University. All rights reserved

* Corresponding author E-mail address: achugunkova@sfu-kras.ru ORCID: 0000-0003-0398-604X
} 


\section{Introduction}

Climate change challenge is now becoming a very important topic. Over the last six decades global mean air temperature reached unprecedented growth rates and this tendency is likely to persist then in future (IPCC, 2014). It is notable that on the territory of Russia there has been more than a two-fold increase of average air temperature: $0.47^{\circ} \mathrm{C}$ against $0.18^{\circ} \mathrm{C}$ per decade (Roshydromet, 2020).

Climate change is closely connected to economy and considerably influences it, so there is a growing body of academic literature on diverse economic effects of warming. For example, temperature and precipitation alterations results in diseases outbreaks among population that reduces economically active population - workforce and GDP level as well (Bosello et al., 2006). Another set of impacts covers changes in energy consumption, fishery, agricultural sector, forestry (Tol, 2009) and natural disasters causing significant damage to infrastructure and material assets (Porfiriev, 2015). Climate change is able to exacerbate some other global challenges, e.g. inequality and poverty by slowing down economic growth of agriculture-dependent developing economies in low-income southern regions where energy demand for cooling will tend to increase in near future (Rehdanz and Maddison, 2005; Dell et al., 2008; Maddison, 2003). Conversely, high-latitude developed countries will benefit from changing climate due to shortening of heating season and decreasing costs for heating services (Labriet et al., 2015).

Being one of the major parts of the global economy, forestry experiences diverse effects: institutional factors, macroeconomic environment and climate change along with its consequences. Climate change can affect forest industry directly or indirectly via changes in qualitative and quantitative assessment of forest growing stocks, and in positive or negative manner.

Since forest is considered as a renewable resource and an important carbon depositor in climate system regulation (Svidenko and Nilsson, 2002; Zamolodchikov et al., 2013; Pyzhev and Vaganov, 2019), a lot of studies are focused on analyzing productive forest function un- der changing climatic conditions, which may increase or decrease growing stocks and, as a result, their commercial potential (Boisvenue and Running, 2006; Liang et al., 2016; Mendelsohn et al., 2016). Positive dynamics in forest productivity may entail more wood harvests and timber supply on global timber markets (Garcia-Gonzalo et al., 2007). Annual global demand dynamics for firewood and biofuel is expected to be positive as well (Kirilenko and Sedjo, 2007; Tian et al., 2016).

Apart from positive impacts, there is a set of climate-induced factors that drive forest degradation and are commonly referred to as natural disturbances. For instance, detrimental windstorms along with shortening soil frost duration may result in windthrow spreading (Saad et al., 2017). Droughts arising from permanent temperature rise with low humidity are usually accompanied with insect infestations (Volney and Fleming, 2000) and frequent wildfires (Flannigan et al., 2000; Shvidenko and Schepaschenko, 2013) that are key stressors undermining sustainability of forest ecosystems and dark needle coniferous tree species in particular (Kharuk et al., 2017). All these kinds of natural disturbances adversely influence logging industry through shrinkage of forest resources available for harvesting. Additionally, economic analysis of these harmful impacts in terms of damage costs accounting still meets many difficulties (Ivantsova et al., 2019).

In the response to climate change the most vulnerable tree species adapt by migration towards more suitable environmental conditions mostly to high-latitude northern areas. In the eastern United States over the past 30 years there was a considerable westward and northward shift of tree habitats that occurred due to the changes in moisture regimes of ecosystems (Fei et al., 2017). In central Siberia the northern forests edge moved a lot further upwards than southern one and changes in species distribution in favor of birch and spruce species domination were identified (Tchebakova et al., 2011). According to some findings, an increase in air temperature in the long run will propel shift of the most vulnerable to drought coniferous towards tundra with milder climate, so in the south stands are expected to be replaced with 
expanding steppes, resulting in $8-10 \%$ diminution in the total area of light and dark-coniferous by 2080 (Tchebakova et al., 2016). As a result, logging activities will move mainly northward following the trajectory of forest migration (Kirilenko and Sedjo, 2007). In European forests under the scenario of infinite greenhouse gases emissions the range of cold-adapted Norway spruce is projected to shrink by over $60 \%$ and be supplanted by Mediterranean oak (Hanewinkel et al., 2013). Diverse forest tree species differently respond to environmental factors alteration, for this reason with warmer and more arid conditions drought-resistant broadleaves are likely to displace more commercially valuable but less resilient coniferous (Drobyshev et al., 2013; Johnstone et al., 2010).

Although logging industry experience indirect consequences of global warming processes, there is a set of direct effects detrimental to forest sector. Extreme weather events in forms of windstorms, hail and heavy rains make performance of harvesting operations dangerous for loggers (Rittenhouse and Rissman, 2015). There is also a risk of getting lost logs while floating down the river due to increased frequency of windstorms and spring floods (Hellmann et al., 2015). Finally, an additional direct impact of climate change on forest industry is a gradual shortening of winter logging season under the rising air temperatures which might result in lesser wood harvested annually (Goltsev and Lopatin, 2013; Chugunkova and Pyzhev, 2020).

In fact, there are few studies on economic consequences of climate change in Russian forestry. For example, Pyzhev (2020) analyzed cause-and-effect relationship between main climatic characteristics of temperature and precipitation and logging volumes for the regions of Siberia and the Far East. In turn, Goltsev and Lopatin (2013) forecasted a reduction in duration of winter-felling season for Tihvin district in Leningrad Oblast.

The same results of shortening winter logging season under the rising air temperatures were obtained for Krasnoyarsk Krai and Irkutsk Oblast in the research by Chugunkova and Pyzhev (2020). The presented study shares the database from (ibid) to reveal the depen- dence of harvested wood volumes on logging season duration on the territory of Siberian regions from 1966 to 2018.

\section{Data and Methods}

In Siberia as well as in some other Russian regions logging companies perform harvest activities during the period, when forest ground freeze enough to enable heavy logging machinery to access forest sites. This period usually spans entirely winter and partially autumn and spring months, so it can be reasonably identified as winter logging season.

Two Siberian regions, Krasnoyarsk Krai and Irkutsk Oblast, were selected as sampling areas for my research due to the fact these regions take leading positions representing the highest share in the total timber volume harvested nationally (Gordeev and Pyzhev, 2015). In 2018, Irkutsk Oblast and Krasnoyarsk Krai accounted for $15 \%\left(35.7\right.$ million $\left.\mathrm{m}^{3}\right)$ and 12 $\%$ (28.6 million $\left.\mathrm{m}^{3}\right)$ of total wood harvested in Russia respectively (UIISS, 2020), thus could be reasonably referred to as the two largest logging territories of Russia.

Two key indicators are in the focus of the analysis: duration of winter logging season and logging volumes.

To estimate the expectable duration of logging season, sets of temperature observations from meteorological stations that are located near felling sites of Krasnoyarsk Krai and in Irkutsk Oblast were used. These stations are Yeniseysk, Boguchany, Achinsk, Minusinsk in Krasnoyarsk Krai and Bratsk, Kirensk, Tulun, Yerbogachen in Irkutsk Oblast. The data were derived from the State Data Holding via Web technology AISORI provided by the All-Russia Research Institute of Hydrometeorological Information - World Data Center (Bulygina et al., 2019). The temperature observations were used to estimate winter logging season duration by each station for the period of 1966-2018 in accordance with the methodology by Chugunkova and Pyzhev (2020).

Data on logging volumes for Krasnoyarsk Krai and Irkutsk Oblast were collated from The Federal Forestry Service's statistical reference book entitled "Forest Management in Russian Federation in 1946-1992 years" (RICFR, 1996). 
Until 1991, Krasnoyarsk Krai covered the territory of the present Khakassia, hence the period of 1966-1991 reflects logging volumes for the expanded territory of Krasnoyarsk Krai. The further information on harvesting operations in 1995, 1998, 2000, 2002, 2004-2006 and 20092018 years was gained from another reference book "Forest complex of Russian Federation and foreign countries" (MSFU, 2008) and UIISS database respectively (UIISS, 2019). To recover missing information on harvested wood volumes, a linear interpolation method was applied. The data were restored based on adjacent given values with a trivial linear equation: $\mathrm{Y}=$ $\mathrm{a}_{0}+\mathrm{a}_{1} \mathrm{~L}$, where $\mathrm{Y}$ is a calendar year and $\mathrm{L}$ is a logging volume in the related year.

To identify the dependence of harvested wood volumes on logging season duration on the territory of Siberian regions from 1966 to 2018, autoregressive distributed lag modeling framework was used. In this model the dependent variable is regressed on its own lagged values and lagged values of an independent variable. ARDL model of $(p, q)$ consists of $p$ lags of independent and $q$ lags of dependent series and is given as:

$L=a_{0}+b_{1} S_{t-1}+b_{2} S_{t-2}+\ldots+b_{p} S_{t-p}+$ $+a_{1} L_{t-1}+a_{2} L_{t-2}+\ldots+a_{2} L_{t-q}+e_{t}$,

where $a_{0}$ is a constant, $b_{1}, b_{2}, \ldots b_{p}$ and $a_{1}, a_{2}$, $\ldots a_{p}$ - model parameters and $e_{t}$ - error term (Demirhan, 2020), L is a logging volume in
Krasnoyarsk Krai or Irkutsk Oblast and S is a winter logging season duration on meteorological station located within the respective region.

\section{Results and conclusion}

Prior to modeling, time series were tested for unit root presence. Both ADF and KPSS unit root tests were used for the modeling purposes, since they provide a bit different approaches to check a stationary process presence. If the null hypothesis is not rejected in ADF (i.e. non-stationarity) or rejected in KPSS (i.e. stationarity) a first-order difference is taken to make a time series stationary, then it is tested again and differenced until the process is stationary. When getting mixed and inconsistent test results, KPSS test seems to be more preferable as it provides more robust results (Table 1).

Next, four ARDL models were evaluated for each region. I used lowest AICc criteria to find out a total number of lag orders for each model and got from 6 to 12 of them for both Krasnoyarsk Krai and Irkutsk Oblast (Tables 2 and 3). Most notably, there were significant coefficients within a distributed lag term in all models, so this lead me to infer that there is a relationship between logging volumes and winter logging season across all considered meteorological stations.

In fact, permanently increasing air temperatures under the global climate change might result in shortening duration of winter

Table 1. The order of differencing (I) in time series data based on ADF and KPSS unit root tests

\begin{tabular}{|c|c|c|}
\hline \multirow{2}{*}{ Indicator } & \multicolumn{2}{|c|}{ I } \\
\hline & ADF & KPSS \\
\hline Logging volumes (Krasnoyarsk Krai) & 2 & 2 \\
\hline Logging volumes (Irkutsk Oblast) & 2 & 1 \\
\hline Logging season duration (Yeniseysk) & 0 & 1 \\
\hline Logging season duration (Boguchany) & 0 & 1 \\
\hline Logging season duration (Achinsk) & 0 & 1 \\
\hline Logging season duration (Minusinsk) & 0 & 1 \\
\hline Logging season duration (Bratsk) & 0 & 1 \\
\hline Logging season duration (Kirensk) & 0 & 1 \\
\hline Logging season duration (Tulun) & 0 & 1 \\
\hline Logging season duration (Yerbogachen) & 0 & 0 \\
\hline
\end{tabular}

Source: elaborated by author. 
Anna V. Chugunkova. Modeling of Logging Industry Dynamics Under the Global Climate Change: the Evidence...

Table 2. Results from ARDL modeling by the meteorological stations of Krasnoyarsk Krai, 1966-2018

\begin{tabular}{|c|c|c|c|c|}
\hline & Yeniseysk & Boguchany & Achinsk & Minusinsk \\
\hline const & $\begin{array}{c}199.986 \\
(181.462)\end{array}$ & $\begin{array}{c}77.378 \\
(237.54)\end{array}$ & $\begin{array}{c}129.123 \\
(166.904)\end{array}$ & $\begin{array}{c}125.804 \\
(160.683)\end{array}$ \\
\hline$a_{1}$ & $\begin{array}{c}-0.553^{*} * * 1 \\
(0.183)\end{array}$ & $\begin{array}{c}-0.472 * * \\
(0.189) \\
\end{array}$ & $\begin{array}{c}-0.62 * * * \\
(0.141)\end{array}$ & $\begin{array}{c}-0.567 * * * \\
(0.14)\end{array}$ \\
\hline $\mathrm{a}_{2}$ & $\begin{array}{c}0.1 \\
(0.201) \\
\end{array}$ & $\begin{array}{c}0.037 \\
(0.199736) \\
\end{array}$ & $\begin{array}{c}0.227 \\
(0.176) \\
\end{array}$ & $\begin{array}{c}0.102 \\
(0.146) \\
\end{array}$ \\
\hline$a_{3}$ & $\begin{array}{l}0.52 * * \\
(0.199)\end{array}$ & $\begin{array}{l}0.455^{*} \\
(0.213)\end{array}$ & $\begin{array}{c}0.6333 * * \\
(0.243)\end{array}$ & $\begin{array}{c}0.578^{* *} \\
(0.23)\end{array}$ \\
\hline$a_{4}$ & $\begin{array}{l}0.013 \\
(0.19)\end{array}$ & $\begin{array}{c}0.113 \\
(0.255)\end{array}$ & $\begin{array}{c}0.042 \\
(0.214)\end{array}$ & $\begin{array}{c}0.107 \\
(0.141)\end{array}$ \\
\hline$a_{5}$ & $\begin{array}{c}-0.499 * * \\
(0.2)\end{array}$ & $\begin{array}{l}-0.255 \\
(0.237)\end{array}$ & $\begin{array}{c}-0.614 * * \\
(0.242)\end{array}$ & $\begin{array}{c}-0.577 * * * \\
(0.204)\end{array}$ \\
\hline$a_{6}$ & $\begin{array}{c}-0.327 * * \\
(0.146)\end{array}$ & $\begin{array}{c}0.172 \\
(0.175)\end{array}$ & $\begin{array}{c}-0.472 * * \\
(0.182)\end{array}$ & $\begin{array}{c}-0.544 * * * \\
(0.185)\end{array}$ \\
\hline$a_{7}$ & & $\begin{array}{l}0.533 * * \\
(0.245)\end{array}$ & & \\
\hline$a_{8}$ & & $\begin{array}{l}-0.013 \\
(0.217) \\
\end{array}$ & & \\
\hline $\mathrm{a}_{9}$ & & $\begin{array}{l}-0.139 \\
(0.217) \\
\end{array}$ & & \\
\hline$a_{10}$ & & $\begin{array}{l}-0.252 \\
(0.197)\end{array}$ & & \\
\hline$a_{11}$ & & $\begin{array}{c}0.279 \\
(0.165) \\
\end{array}$ & & \\
\hline$a_{12}$ & & $\begin{array}{c}0.141 \\
(0.218) \\
\end{array}$ & & \\
\hline $\mathrm{b}_{1}$ & $\begin{array}{c}23.1^{*} \\
(12.287) \\
\end{array}$ & $\begin{array}{l}-4.689 \\
(17.108)\end{array}$ & $\begin{array}{c}9.776 \\
(11.384) \\
\end{array}$ & $\begin{array}{l}-4.226 \\
(11.052)\end{array}$ \\
\hline$b_{2}$ & $\begin{array}{c}24.277 \\
(16.729)\end{array}$ & $\begin{array}{c}2.237 \\
(14.154)\end{array}$ & $\begin{array}{c}14.69 \\
(17.085)\end{array}$ & $\begin{array}{c}13.435 \\
(18.058)\end{array}$ \\
\hline$b_{3}$ & $\begin{array}{c}27.308 \\
(19.678) \\
\end{array}$ & $\begin{array}{c}-4.292 \\
(18.899) \\
\end{array}$ & $\begin{array}{l}-12.141 \\
(18.574) \\
\end{array}$ & $\begin{array}{l}-13.887 \\
(17.746) \\
\end{array}$ \\
\hline $\mathrm{b}_{4}$ & $\begin{array}{c}1.787 \\
(18.386)\end{array}$ & $\begin{array}{l}-27.418 \\
(18.006)\end{array}$ & $\begin{array}{c}-35.56^{*} \\
(17.73)\end{array}$ & $\begin{array}{c}-43.766^{* *} \\
(19.42)\end{array}$ \\
\hline$b_{5}$ & $\begin{array}{c}18.035 \\
(16.091)\end{array}$ & $\begin{array}{l}-24.039 \\
(22.348)\end{array}$ & $\begin{array}{l}-12.276 \\
(17.557)\end{array}$ & $\begin{array}{l}-29.07 * \\
(16.395)\end{array}$ \\
\hline $\mathrm{b}_{6}$ & $\begin{array}{c}5.196 \\
(13.144)\end{array}$ & $\begin{array}{l}-32.171 \\
(24.096)\end{array}$ & $\begin{array}{c}1.122 \\
(13.125)\end{array}$ & $\begin{array}{c}-16.654^{*} \\
(9.323)\end{array}$ \\
\hline$b_{7}$ & & $\begin{array}{c}-48.251 * * \\
(22.29)\end{array}$ & & \\
\hline $\mathrm{b}_{8}$ & & $\begin{array}{c}-57.885^{*} \\
(28.513) \\
\end{array}$ & & \\
\hline$b_{9}$ & & $\begin{array}{c}-67.421^{* * *} \\
(20.059) \\
\end{array}$ & & \\
\hline $\mathrm{b}_{10}$ & & $\begin{array}{c}-53.15^{* *} \\
(19.803) \\
\end{array}$ & & \\
\hline $\mathrm{b}_{11}$ & & $\begin{array}{c}-35.406 * * \\
(14.966) \\
\end{array}$ & & \\
\hline$b_{12}$ & & $\begin{array}{c}-43.593^{*} \\
(21.428)\end{array}$ & & \\
\hline $\mathrm{R}^{2}$ & 0.521 & 0.762 & 0.624 & 0.653 \\
\hline
\end{tabular}

Source: elaborated by author.

${ }^{1}$ The symbols ${ }^{* * *},{ }^{* *}$, ${ }^{*}$ hereinafter denotes significance at $1 \%, 5 \%$ and $10 \%$ levels correspondingly. 
Anna V. Chugunkova. Modeling of Logging Industry Dynamics Under the Global Climate Change: the Evidence...

Table 3. Results from ARDL modeling by the meteorological stations of Irkutsk Oblast, 1966-2018

\begin{tabular}{|c|c|c|c|c|}
\hline & Bratsk & Kirensk & Tulun & Yerbogachen \\
\hline const & $73.876(207.831)$ & $\begin{array}{l}256.941 \\
(211.43) \\
\end{array}$ & $\begin{array}{c}154.642 \\
(189.235)\end{array}$ & $\begin{array}{c}-9905.47^{*} \\
(5347.49) \\
\end{array}$ \\
\hline$a_{1}$ & $\begin{array}{c}0.649 * * * \\
(0.201345)\end{array}$ & $\begin{array}{c}0.646^{* * * *} \\
(0.19)\end{array}$ & $\begin{array}{c}0.528^{* * *} \\
(0.172) \\
\end{array}$ & $\begin{array}{c}0.455^{* * *} \\
(0.129)\end{array}$ \\
\hline $\mathrm{a}_{2}$ & $\begin{array}{l}0.063 \\
(0.195)\end{array}$ & $\begin{array}{c}0.056 \\
(0.271) \\
\end{array}$ & $\begin{array}{c}0.089 \\
(0.184) \\
\end{array}$ & $\begin{array}{l}0.271^{*} \\
(0.152) \\
\end{array}$ \\
\hline$a_{3}$ & $\begin{array}{l}-0.219 \\
(0.207)\end{array}$ & $\begin{array}{c}0.005 \\
(0.214)\end{array}$ & $\begin{array}{l}-0.24 \\
(0.225)\end{array}$ & $\begin{array}{c}0.19 \\
(0.145)\end{array}$ \\
\hline$a_{4}$ & $\begin{array}{l}0.387^{*} \\
(0.215)\end{array}$ & $\begin{array}{l}0.521 * * \\
(0.225)\end{array}$ & $\begin{array}{c}0.572 * * \\
(0.219)\end{array}$ & $\begin{array}{c}0.095 \\
(0.177) \\
\end{array}$ \\
\hline$a_{5}$ & $\begin{array}{c}0.08 \\
(0.164)\end{array}$ & $\begin{array}{l}0.161 \\
(0.3)\end{array}$ & $\begin{array}{l}0.116 \\
(0.14)\end{array}$ & $\begin{array}{c}0.081 \\
(0.164)\end{array}$ \\
\hline$a_{6}$ & $\begin{array}{c}-0.671 * * * \\
(0.15)\end{array}$ & $\begin{array}{c}-0.777 * * * \\
(0.245)\end{array}$ & $\begin{array}{c}-0.656^{* * *} \\
(0.14)\end{array}$ & $\begin{array}{c}-0.438^{* * *} \\
(0.117)\end{array}$ \\
\hline $\mathrm{a}_{7}$ & $\begin{array}{l}0.371^{*} \\
(0.203)\end{array}$ & $\begin{array}{c}0.006 \\
(0.189)\end{array}$ & $\begin{array}{c}0.117 \\
(0.193)\end{array}$ & \\
\hline $\mathrm{a}_{8}$ & $\begin{array}{l}-0.056 \\
(0.198) \\
\end{array}$ & $\begin{array}{c}0.104 \\
(0.261)\end{array}$ & $\begin{array}{c}0.157 \\
(0.176)\end{array}$ & \\
\hline $\mathrm{a}_{9}$ & & $\begin{array}{c}-0.271 \\
(0.22)\end{array}$ & & \\
\hline $\mathrm{a}_{10}$ & & $\begin{array}{c}0.284 \\
(0.276)\end{array}$ & & \\
\hline$a_{11}$ & & $\begin{array}{c}0.182 \\
(0.258)\end{array}$ & & \\
\hline $\mathrm{b}_{1}$ & $\begin{array}{c}1.749 \\
(14.18)\end{array}$ & $\begin{array}{l}10.4189 \\
(11.788) \\
\end{array}$ & $\begin{array}{l}-3.861 \\
(13.613) \\
\end{array}$ & $\begin{array}{c}-2.098 \\
(12.577) \\
\end{array}$ \\
\hline $\mathrm{b}_{2}$ & $\begin{array}{c}25.901 \\
(19.836) \\
\end{array}$ & $\begin{array}{c}34.619 * * \\
(14.589) \\
\end{array}$ & $\begin{array}{c}22.234 \\
(15.204) \\
\end{array}$ & $\begin{array}{l}11.495 \\
(10.21) \\
\end{array}$ \\
\hline$b_{3}$ & $\begin{array}{l}59.696^{* *} \\
(21.954) \\
\end{array}$ & $\begin{array}{c}95.174 * * * \\
(22.434) \\
\end{array}$ & $\begin{array}{c}80.715^{* * * *} \\
(20.463) \\
\end{array}$ & $\begin{array}{c}44.259^{* * *} \\
(9.114) \\
\end{array}$ \\
\hline $\mathrm{b}_{4}$ & $\begin{array}{l}45.195^{*} \\
(23.561)\end{array}$ & $\begin{array}{c}93.081 * * * \\
(28.897)\end{array}$ & $\begin{array}{c}75.733^{* * * *} \\
(19.329)\end{array}$ & $\begin{array}{c}16.566 \\
(13.413) \\
\end{array}$ \\
\hline $\mathrm{b}_{5}$ & $\begin{array}{l}59.904 * * \\
(23.355)\end{array}$ & $\begin{array}{c}98.895^{* * *} \\
(25.025)\end{array}$ & $\begin{array}{c}73.122^{* * * *} \\
(20.559)\end{array}$ & $\begin{array}{c}13.437 \\
(12.864) \\
\end{array}$ \\
\hline $\mathrm{b}_{6}$ & $\begin{array}{l}58.83 * * * \\
(18.997) \\
\end{array}$ & $\begin{array}{l}49.239^{*} \\
(26.361) \\
\end{array}$ & $\begin{array}{l}54.826^{* *} \\
(22.277) \\
\end{array}$ & $\begin{array}{c}-28.268^{*} \\
(15.125) \\
\end{array}$ \\
\hline $\mathrm{b}_{7}$ & $\begin{array}{c}46.205^{* * *} \\
(16.297)\end{array}$ & $\begin{array}{l}43.577^{*} \\
(22.906)\end{array}$ & $\begin{array}{c}65.822^{* * * *} \\
(20.155)\end{array}$ & \\
\hline $\mathrm{b}_{8}$ & $\begin{array}{c}41.28 * * * \\
(12.215)\end{array}$ & $\begin{array}{c}21.757 \\
(22.616)\end{array}$ & $\begin{array}{c}48.416^{* * *} \\
(16.21)\end{array}$ & \\
\hline $\mathrm{b}_{9}$ & & $\begin{array}{c}20.099 \\
(20.315)\end{array}$ & & \\
\hline $\mathrm{b}_{10}$ & & $\begin{array}{l}37.356^{*} \\
(18.589) \\
\end{array}$ & & \\
\hline $\mathrm{b}_{11}$ & & $\begin{array}{l}26.074^{*} \\
(14.169) \\
\end{array}$ & & \\
\hline $\mathrm{R}^{2}$ & 0.763 & 0.873 & 0.793 & 0.773 \\
\hline
\end{tabular}

Source: elaborated by author. 
logging season on the territory of Siberian regions (Chugunkova and Pyzhev, 2020). As a consequence, this means less wood harvests per season, so logging industry could become unprofitable in the long run. To reduce such a negative impact, mitigation and, that is more important, adaptation activities in forestry are sorely needed.

\section{References}

Bosello F., Roson R., Tol, R.S.J. (2006). Economy-wide estimates of the implications of climate change: Human health. In Ecological Economics, 58(3), 579-591. DOI: 10.1016/j.ecolecon.2005.07.032.

Boisvenue, C., Running, S.W. (2006). Impacts of climate change on natural forest productivity - evidence since the middle of the $20^{\text {th }}$ century. In Global Change Biology, 12(5), 862-882. DOI: 10.1111/j.1365-2486.2006.01134.x.

Bulygina, O., Veselov, V., Razuvaev, V., Aleksandrova, T. Description of Hourly Data Set of Meteorological Parameters Obtained at Russian Stations. Available online: http://meteo.ru/english/climate/ descrip12.htm (accessed on 5 December 2019).

Chugunkova, A.V., Pyzhev, A.I. Impacts of Global Climate Change on Duration of Logging Season in Siberian Boreal Forests. In Forests, 11, 756. DOI: 10.3390/f11070756.

Dell M., Jones B.F., Olken B.A. (2008). Climate Change and Economic Growth: Evidence from the Last Half Century. National Bureau of Economic Research. Available at: http://www.nber.org/papers/ w14132.pdf (accessed: 05.12.18).

Demirhan, H. (2020). dLagM: An R package for distributed lag models and ARDL bounds testing. In PLoS ONE, 15(2), e0228812. DOI: 10.1371/journal.pone.0228812.

Drobyshev, I., Gewehr, S., Berninger, F., Bergeron, Y. (2013). Species specific growth responses of black spruce and trembling aspen may enhance resilience of boreal forest to climate change. In Journal of Ecology, 101(1), 231-242. DOI: 10.1111/1365-2745.12007.

Fei, S., Desprez, J.M., Potter, K.M., Jo, I., Knott, J.A., Oswalt, Ch.M. (2017). Divergence of species responses to climate change. In Science Advances, 3(5), 1-9. DOI: 10.1126/sciadv.1603055.

Flannigan, M.D., Stocks, B.J., Wotton, B.M. (2000). Climate change and forest fires. In Science of the Total Environment, 262(3), 221-229. DOI: 10.1016/S0048-9697(00)00524-6.

Garcia-Gonzalo, J., Peltola, H., Briceño-Elizondo, E., Kellomäki, S. (2007). Effects of climate change and management on timber yield in boreal forests, with economic implications: A case study. In Ecological Modelling, 209(2-4), 220-234. DOI: 10.1016/j.ecolmodel.2007.06.021.

Goltsev, V., Lopatin, E. (2013). The impact of climate change on the technical accessibility of forests in the Tikhvin District of the Leningrad Region of Russia. In International Journal of Forest Engineering, 24(2), 148-160. DOI: 10.1080/19132220.2013.792150.

Gordeev, R.V., Pyzhev, A.I. (2015). Analiz global'noi konkurentosposobnosti Rossiiskogo lesopromyshlennogo kompleksa [Analysis of the global competitiveness of the Russian timber industry], In ECO, 6(492), 109-130. DOI: 10.30680/ECO0131-7652-2015-6-109-130.

Hanewinkel, M., Cullmann, D.A., Schelhaas, M.-J., Nabuurs, G.-J., Zimmermann, N.E. (2013). Climate change may cause severe loss in the economic value of European forest land. In Nature Climate Change, 3, 203-207. DOI: 10.1038/nclimate1687.

Hellmann, L., Tegel, W., Kirdyanov, A. V., Eggertsson, Ó., Esper, J., Agafonov, L., Nikolaev, A.N., Knorre, A.A., Myglan, V.S., Churakova, (Sidorova) O., Schweingruber, F.H., Nievergelt, D., Verstege, A., Büntgen, U. (2015). Timber Logging in Central Siberia is the Main Source for Recent Arctic Driftwood. In Arctic, Antarctic, and Alpine Research, 47(3), 449-460. DOI: 10.1657/ AAAR0014-063.

IPCC, 2014. Climate Change 2014: Synthesis Report. Contribution of Working Groups I, II and III to the Fifth Assessment Report of the Intergovernmental Panel on Climate Change [Core Writing Team, R.K. Pachauri and L.A. Meyer (eds.)]. Geneva, Switzerland, 151 p. 
Ivantsova, E.D., Pyzhev, A.I., Zander, E.V. (2019). Economic Consequences of Insect Pests Outbreaks in Boreal Forests: A Literature Review. In Journal of Siberian Federal University. Humanities \& Social Sciences, 627-642. doi:10.17516/1997-1370-0417.

Johnstone, J.F., Hollingsworth, T.N., Chapin, F.S., Mack, M.C. (2010). Changes in fire regime break the legacy lock on successional trajectories in Alaskan boreal forest. In Global Change Biology, 16 (4), 1281-1295. DOI: 10.1111/j.1365-2486.2009.02051.x.

Kharuk, V.I., Im, S.T., Petrov, I.A., Golyukov, A.S., Ranson, K.J., Yagunov, M.N. (2017). Climate-induced mortality of Siberian pine and fir in the Lake Baikal Watershed, Siberia. In Forest Ecology and Management, 384, 191-199. DOI: 10.1016/j.foreco.2016.10.050.

Kirilenko, A.P., Sedjo, R.A. (2007). Climate change impacts on forestry. In PNAS, 104(50), 1969719702. DOI: 10.1073/pnas.0701424104.

Labriet, M., Joshi, S.R., Vielle, M., Holden, P.B., Edwards, N.R., Kanudia, A., Loulou, R., Babonneau, F. (2015). Worldwide impacts of climate change on energy for heating and cooling. In Mitigation and Adaptation Strategies for Global Change, 20(7), 1111-1136. DOI: 10.1007/s11027-013-9522-7.

Liang, J. [et al.] (2016). Positive biodiversity-productivity relationship predominant in global forests. In Science, 354(6309), 196-209. DOI: 10.1126/science.aaf8957.

Maddison, D. (2003). The amenity value of the climate: the household production function approach. In Resource and Energy Economics, 25(2), 155-175. DOI: 10.1016/S0928-7655(02)00024-6.

Mendelsohn, R., Prentice, I.C., Schmitz, O., Stocker, B., Buchkowski, R., Dawson, B. (2016). The Ecosystem Impacts of Severe Warming. In American Economic Review, 106(5), 612-614. DOI: 10.1257/aer. p20161104.

Moscow State Forest University (MSFU) (2008). Lesnoi kompleks Rossiiskoi Federatsii I zarubezhnyh stran [Forest complex of Russian Federation and foreign countries]. Moscow, 392 p.

Porfiriev, B. (2015). Climate change as a major slow-onset hazard to development: an integrated approach to bridge the policy gap. In Environmental Hazards (special issue), 14(2), 187-191. DOI: 10.1080/17 477891.2015.1019823.

Pyzhev, A.I., Vaganov, E.A. (2019). Rol' Rossiyskih lesov v realizacii Parizhskogo klimaticheskogo soglasheninya: vozmozhnosti I riski [Global Climate Change Economics: The Role of Russian Forests]. In ECO, 11, 27-44. DOI: 10.30680/ECO0131-7652-2019-11-27-44

Pyzhev, A.I. (2020). Global'nye izmeneniia klimata i ob"emy lesozagotovok regionov Sibiri v 19461992 godakh [Global climate change and logging volumes in Siberian regions from 1946 to 1992]. In Terra Economicus, 18(1), 140-153. DOI: 10.18522/2073-6606-2020-18-1-140-153

Rehdanz, K., Maddison, D. (2005). Climate and happiness. In Ecological Economics, 52(1), 111-125. DOI: $10.1016 /$ j.ecolecon.2004.06.015.

Research and Information Center on Forest Resources (RACFR) (1996). Lesopol'zovanie v Rossiiskoi Federatsii v 1946-1992 godakh [Forest Management in Russian Federation in 1946-1992 years]. Moscow, 313 p.

Rittenhouse, Ch.D., Rissman, A.R. (2015). Changes in winter conditions impact forest management in north temperate forests. In Journal of Environmental Management, 149, 157-167. DOI: 10.1016/j.jenvman.2014.10.010.

Russian federal service for hydrometeorology and environmental monitoring (Roshydromet) (2020). Doklad ob osobennostiakh klimata na territorii Rossiiskoi Federatsii [A report on climate features on the territory of the Russian Federation in 2019]. Moscow, 97 p.

Saad, Ch., Boulanger, Y., Beaudet, M., Gachon, Ph., Ruel, J.-C., Gauthier, S. (2017). Potential impact of climate change on the risk of windthrow in eastern Canada's forests. In Climatic Change, 143(3-4), 487-501. DOI: 10.1007/s10584-017-1995-z.

Shvidenko, A., Nilsson, S. (2002). Dynamics of Russian Forests and the Carbon Budget in 19611998: An Assessment Based on Long-Term Forest Inventory Data. In Climatic Change, 5(1-2), 5-37. DOI: $10.1023 / \mathrm{A}: 1020243304744$.

Shvidenko, A.Z., Schepaschenko, D.G. (2013). Climate change and wildfires in Russia. In Contemporary Problems of Ecology, 6(7), 683-692. DOI: 10.1134/S199542551307010X. 
Tchebakova, N.M., Parfenova, E.I., Korets, M.A., Conard, S.G. (2016). Potential change in forest types and stand heights in central Siberia in a warming climate. In Environmental Research Letters, 11(3), 1-16. DOI: 10.1088/1748-9326/11/3/035016.

Tchebakova, N.M., Parfenova, E.I., Soja, A.J. (2011). Climate change and climate-induced hot spots in forest shifts in central Siberia from observed data. In Regional Environmental Change, 11(4), 817-827. DOI: $10.1007 / \mathrm{s} 10113-011-0210-4$.

Tian, X., Sohngen, B., Kim, J.B., Ohrel, S., Cole, J. (2016). Global climate change impacts on forests and markets. In Environmental Research Letters, 11(3), 1-10. DOI: 10.1088/1748-9326/11/3/035011.

Tol, R.S.J. (2009). The Economic Effects of Climate Change. In Journal of Economic Perspectives, 23(2), 29-51. DOI: 10.1257/jep.23.2.29.

Unified Interdepartmental Information and Statistical System (UIISS). Harvested Wood Volume. Available at: https://fedstat.ru/indicator/37848 (accessed on 27 August 2019).

Volney, W.J.A., Fleming, R.A. (2000). Climate change and impacts of boreal forest insects. In Agriculture, Ecosystems \& Environment, 82(1-3), 283-294. DOI: 10.1016/S0167-8809(00)00232-2.

Zamolodchikov, D.G., Grabovskii, V.I., Korovin, G.N., Gitarskii, M.L., Blinov, V.G., Dmitriev, V.V., Kurz, W.A. (2013). Carbon budget of managed forests in the Russian Federation in 1990-2050: Post-evaluation and forecasting. In Russian Meteorology Hydrology, 38(10), 701-714. DOI: 10.3103/S1068373913100087.

\title{
Моделирование динамики развития лесозаготовительной промышленности под влиянием глобального изменения климата: пример регионов Сибири
}

\author{
A.В. Чугункова \\ Сибирский федеральный университет \\ Российская Федерачия, Красноярск
}

\begin{abstract}
Аннотация. Лесное хозяйство как одна из отраслей экономки испытывает на себе влияние множества факторов, и глобальное изменение климата является одним из них. Климатические изменения могут влиять на лесную отрасль как напрямую, так и косвенно через изменение количественных и качественных характеристик леса, а также позитивным либо негативным образом. Изучение основных экономических последствий глобального изменения климата для лесного хозяйства России требует к себе более детального внимания со стороны академического сообщества и органов власти. Одним из таких последствий является сокращение длительности зимнего лесозаготовительного сезона, что может привести к уменьшению объемов заготовки древесины в долгосрочной перспективе. На основе данных об объемах заготовки древесины в Красноярском крае и Иркутской области, а также длительности зимнего сезона по метеостанциям указанных регионов за период 1966-2018 гг. было построено восемь моделей ARDL, которые показали наличие зависимости объемов заготовки древесины от длительности лесозаготовительного сезона по всем рассмотренным метеостанциям. Для того чтобы минимизировать негативное влияние потепления на лесную отрасль в виде предстоящего сокращения объемов заготавливаемой древесины, необходима реализация комплекса мер по адаптации отрасли к изменяющемуся климату.
\end{abstract}


Ключевые слова: глобальное изменение климата, лесное хозяйство, лесозаготовительный сезон, объем заготовки древесины, модель авторегрессии и распределенного лага.

Исследование выполнено за счет гранта Российского научного фонда (проект № 19-18-00145). Автор благодарит доцента А.И. Пыжева за полезные замечания и предложения по моделированию временных рядов.

Научная специальность: 08.00.05 — экономика и управление народным хозяйством. 